University of Zurich

Department of Economics

Working Paper Series

ISSN 1664-7041 (print)

ISSN 1664-705X (online)

Working Paper No. 144

God does not play dice, but people should: random selection in politics, science and society

Bruno S. Frey and Lasse Steiner

March 2014 
GOD DOES NOT PLAY DICE, BUT PEOPLE SHOULD: RANDOM SELECTION IN POLITICS, SCIENCE AND SOCIETY

\author{
by \\ Bruno S. Frey ${ }^{1}$ \\ University of Zurich \\ Zeppelin University \\ CREMA - Center for Research in Economics, Management and the Arts, Switzerland \\ and \\ Lasse Steiner ${ }^{2}$ \\ University of Zurich \\ University of California at Berkeley
}

\begin{abstract}
This paper discusses and proposes random selection as a component in decision-making in society. Random procedures have played a significant role in history, especially in classical Greece and the medieval city-states of Italy. We examine the important positive features of decisions by random mechanisms. Random processes allow representativeness with respect to individuals and groups. They significantly reduce opportunities to influence political decisions by means of bribery and corruption and decrease the large expenses associated with today's democratic election campaigns. Random mechanisms can be applied fruitfully to a wide range of fields, including politics, the judiciary, the economy, science and the cultural sector. However, it is important that random selection processes are embedded in appropriately designed institutions.
\end{abstract}

Keywords: Random selection, lot, democracy, representativeness, corruption

\footnotetext{
${ }^{1}$ Professor (em.), University of Zurich, Konstanz and Warwick University, Professor, Zeppelin University, Friedrichshafen. He is also Research Director of CREMA. E-mail: bruno.frey@econ.uzh.ch

${ }^{2}$ Research Associate, University of Zurich, Switzerland; Visiting Scholar, School of Law, University of California at Berkeley, E-mail: lasse.steiner@berkeley.edu
} 


\section{GOD DOES NOT PLAY DICE, BUT PEOPLE SHOULD: RANDOM SELECTION IN POLITICS, SCIENCE AND SOCIETY}

\section{Introduction}

Despite the huge range of decisions which face individuals, groups and societies, the range of decision methods which are employed is often restricted to a sparse handful of options. Frequently, market mechanisms and political processes are considered the only viable decision-making mechanisms in a society. However, restricting the set of decision mechanisms to market and state does not reflect all the approaches to reaching decisions which can be observed in reality. As a consequence, opportunities to find appropriate decision-making mechanisms for socially relevant questions are often wasted.

This article discusses a social selection process which is rarely used at present and which is often confronted by fierce resistance. Reaching decisions by using random procedures tends to be regarded as arbitrary and ill-founded. This notion also seems to be behind Einstein's quote, reproduced in our title: "God does not play dice". Under closer examination, though, random decision mechanisms reveal interesting characteristics which set them apart from other more frequently used procedures. There is no perfect social decision-making system. In this paper, the advantages and disadvantages of random selection are identified and compared with other decision-making mechanisms. We show that random selection is a reasonable solution in many areas of society and politics. Due to its positive properties, random selection emerges as a mechanism which should be considered and applied more often in future political and academic contexts.

We proceed in the following manner. The section immediately below discusses the most important positive and negative aspects of random selection mechanisms. The third section compares random selection to various other possible social decision making procedures, and the fourth section introduces several potential applications of random selection in politics, business, science, and the cultural sector. We discuss how representativeness of a population is reached, how the costs of decision making decrease, and how rent-seeking can be reduced. The last section offers a concluding evaluation of random selection as a social decisionmaking procedure. 


\section{Properties of Random Selections}

The term randomness is often associated with arbitrariness or even despotism in the political sphere. We understand randomness strictly as statistical probability; it has nothing to do with arbitrariness but, rather to the contrary, exhibits a strict mathematical regularity in a sufficiently large sample or over a sufficient number of iterations. In a random decision, human influence is deliberately suppressed. The result depends solely on mathematical coincidence. Randomness can be achieved in various ways, for instance, by drawing variegated balls from a ballot box or using computer programs. One popular example is the drawing of lottery numbers on TV, where numbered balls fall out of a transparent, mechanically moving cylinder or sphere and thus decide the lottery winners.

Random decisions have at least four important advantages over other decision-making procedures (see e.g. Intriligator 1973; Elster 1989; Carson and Martin 1999; McCormick 2006; Buchstein 2009a, 2010; Zeitoun et al. 2014):

(a) Random decisions produce a precise representativeness of the underlying population. Imagine an urn in which five red, three green and two white balls represent the population. When drawn randomly, each ball has the same probability of being selected. Consequently, the chance of drawing a red ball is 50 percent, of a green ball 30 percent and of a white ball 20 percent. In a single draw, of course, it can be the case that a white ball is drawn - a property which is only little represented in the population. The probability of this happening is exactly 20 percent, neither higher nor lower. If a larger number of balls are drawn in consecutive rounds, a red ball will be drawn in (close to) half of the cases. The method can be applied to achieve a representative sample from a population and is therefore used routinely in wellconducted surveys. For example, the Swiss census, which is held each decade, has been carried out since 2010 not by means of a survey of all inhabitants, but with a representative, random selection of about $5 \%$ of the population (BFS 2011). Due to the smaller sample, the socio-demographic characteristics and economic conditions of the respondents can be captured in a more careful and more detailed manner. Random processes prevent systematic discrimination against a feature represented in the 
underlying pool, such as race or gender. A group is represented according to its significance in a population. This offers a chance to groups that otherwise are not taken into account in the political process. Random selection meets egalitarian standards (see McCormick 2006, referring to Aristotle).

(b) Properties, groups or views that were disregarded at the time of selection or that were deemed to be unimportant are automatically represented according to their importance in the population. In this respect, the random mechanism has a substantial advantage over the establishment of quotas. Quotas can only be set if the corresponding dimensions (such as gender or age) are considered relevant. Random selection enables previously neglected aspects, ideas and perspectives to find attention.

(c) Random selection promotes the stability and continuity of representation, when the population is characterized by strongly contrasting groups. Each of them has a chance to be represented in the future, even if so far the counterparty was dominant. This aspect played an important role in classical Athens and in the Italian city-states of the Middle Ages, where prosperity was repeatedly threatened by political unrest and civil wars (Hansen 1991; Duxbury 1999; Stone 2009).

(d) The inherent cost of a decision process can be reduced. Direct process costs are, for example, connected with carrying out a census for the whole population instead of a subsample or the enormous cost of candidates' campaigns for political elections. In addition, random selection prevents an illegitimate influence on the decisions to be taken and so reduces indirect process cost. This is especially important in political decisions in which organized interest groups seek to influence the social outcome in their favor (see e.g.Hayek 1979). Interest groups will spend fewer financial resources to influence policy, since a random process cannot be controlled by human intervention. Spending money trying to influence a random process would be wasted. In contrast, the result of other social decision-making processes such as democratic elections can be influenced by means of advertising and corruption.

Random decisions also have disadvantages against other decision-making procedures:

(a) Random procedures do not consider desirable properties; in particular, they do not differ between knowledgeable experts and poorly informed laypeople. Randomly 
selected individuals may find themselves unable to deal with a particular task. For this reason, the selection of individuals by a random process is usually supplemented by additional procedures. The population is restricted to those who are believed to be able to fulfill the tasks competently. For example, the random selection of the Coptic Pope is limited to a group of three people preselected by the church authorities.

(b) A random method may affect the sense of responsibility, especially because those selected do not have to worry about re-election. It may negatively affect public officials' sense of accountability or their responsiveness. This problem can be mitigated by additional rules. The pool may be restricted to individuals who may be expected to take their tasks and duties seriously. In addition, it can be stipulated that elected individuals must justify their actions and are punished for illegal or illconsidered actions.

(c) People may (wrongly) take decisions by a random mechanism to be "irrational" or "arbitrary" and therefore to be illegitimate. Empirical studies suggest indeed that the general population perceives random decisions to be poorer than decisions by public authorities, by simple voting processes or by the use of the price system (Frey and Pommerehne 1990). The policies can therefore be difficult or impossible to implement. For this reason, random decisions cannot be used in all situations, but only where the population affected considers them to be acceptable and useful.

Random decision-making processes are often combined with other procedures (Silvano 1990; Manin 1997). The nomination of candidates may be made by lot or by randomly chosen nominators; in a second step, the magistrates may be selected from the pool of individuals nominated (see figure 1 in McCormick 2006). A good example is the city-state of Venice from the 7th to 18th century (see also McCormick 2006, referring to Guicciardini and Machiavelli). The election of the Doge, who was elected for life, was crucial for this city. There was, however, always the risk that one of the powerful families would exert political pressure or bribery and so manage to occupy the position of the Doge at the expense of other families. The electoral system was therefore crafted as a mixture of decision by lot and a public, free, and carefully conducted discussion and resolution. All of the members of the Grand Council, who at some times numbered up to up to 1,800 in total, were eligible for the position of the Doge. One ball was deposited in an urn for each member. A ten-year-old boy 
(Ballottino) was chosen on St. Mark's Square. This Ballottino initially drew 30 balls to choose the electoral college. The selection procedure included several further rounds, in which voting and chance alternated.

Other Italian city states of the Middle Ages, such as Florence, used elements of a random selection process to determine their executive (Silvano 1990; Dumler 2001). Even today, the Coptic Pope is appointed through ballottinos. The bishops predetermine three candidates that form the pool. The choice between them is made by a boy who draws a name from an urn containing three balls (Boochs 2009). This process is significantly different from the choice of the Western Pope, in which the choice is determined exclusively by simple voting of the Council of Cardinals.

The discussion reveals that random methods have great benefits, but can only be used in a limited set of situations and must be supplemented by other methods. This decision-making system should be given far more attention than is currently the case. New decision-making procedures should always be thoroughly tested to gain a clear understanding of their potentialities. As our discussion in the next section shows, other social decision-making systems similarly have both advantages and disadvantages: There is no perfect way to reach political decisions. Rather, the benefits and costs of different social decision-making mechanisms must be compared.

\section{Traditional Social Decision-Making Systems}

Random decisions can be considered to be a specific way to reach decisions at the level of society. In order to understand their character, it is important to compare them to other social decision-making systems. Following Dahl and Lindblom (1953) and Frey (1983), the various systems can be classified according to the number of different components. We distinguish systems with two, three, or more components.

The dual conception compares the price system with one alternative method. The focus is on the contrast between free markets and central planning. This traditional and commonly used distinction is crude, but nevertheless often forms the basis of economic policy planning. It emphasizes the contrast between decentralized and centralized control of the economy and society. This dichotomy is too simple. For example, plans can be sanctioned by democratic 
decision. The market/plan duality obstructs the development of new concepts, especially when coupled with the capitalism/socialism duality. A planned economy is also possible with capitalist property structures, as was seen in the Third Reich, and socialism does not rule out market-based elements, as can be seen today in China.

A duality is often constructed between the market and voting. The market is considered to be "economic" while voting for social decisions to be "political". This comparison is more useful than the distinction between market and plan, because knowledge of the two decision mechanisms is more advanced. It is well known under which conditions the price system or direct referenda lead to an efficient allocation of resources and under which conditions markets and elections function less well, often referred to respectively as market failures and policy failures. The most important feature of a perfect market is the paradox that the selfinterest of the participants leads to the highest common welfare (Smith 1776). The market even has a "civilizing" effect, because no one wants to do business with villains and fraudsters, according to Montesquieu (1749), Condorcet (1795) and Kant (1795).

A less established view compares the processes of exit and voice (Hirschman 1970). They describe the basic options available to individuals and groups, if the performance of an institution - a company, a private or public organization or a government - is considered lacking. In orthodox (i.e. neo-classical) economics, exit is the only possible reaction. For example, if the price of a company's commodity is higher than that of competitors, consumers turn to other suppliers, or when a government makes bad decisions, the inhabitants tend to emigrate. Political scientists focus mainly on opposition or protest (i.e. voice). The people in charge are induced to improve performance because otherwise they run the risk of losing their position. This reaction mechanism functions only under certain conditions. In an extreme dictatorship, for example, the ruler makes a big effort to suppress both exit and voice.

The classification of two social decision-making mechanisms is useful because it organizes the entire space of possibilities and point out differences. However, the dual view tends to induce the fallacy that if one mechanism fails, the other one is the only solution. As a consequence, the state is summoned too often if a market is not functioning optimally, without considering that the state may even perform worse.

Exchange, love and threat represent a threefold principle of organization (Boulding 1968). In addition to the market building on the principle of exchange, the two other social decisionmaking procedures are based on entirely different mechanisms. Love is based on the principle 
that "it makes me happy, if I can do you any good." It plays an important role in small groups and in the family. Exchange and interaction as positive-sum game result in benefits for all. However, it cannot often be applied, and collapses easily when one agent seeks to gain an advantage at the expense of others. Threat is based on the principle that "if you do not do what I want, I will inflict damage on you." This method is widely used, for example in strikes and especially between nations. It can easily lead to a negative-sum game in which all parties lose.

Market, democracy, hierarchy, and bargaining distinguish social decision-making systems which are dominant under many conditions and which exhibit well-analyzed properties (Dahl and Lindblom 1953). State actions are based primarily on decisions by means of democracy and hierarchy. In representative democracies, citizens can elect their representatives in parliament, and in semi-direct democracies, such as Switzerland, they can also determine decisions on factual issues. Democratic procedures are able to overcome some problems that occur with the use of the price mechanism. This is especially true for public goods whose use is open to all individuals, even if they have not paid for them, and external effects - positive or negative effects that are not reflected in prices (Olson 1965; Olken 2010). For all democratic procedures there is a risk of strategic voting; individuals cast a vote deviating from their true preferences in order to obtain benefits at the expense of others (e.g. Niemi 1984). This risk is particularly pronounced in systems with more than one vote, such as cumulative, positional, point, or approval voting (e.g. Merrill and Nagel 1987).

Hierarchical decision-making systems are mainly found in bureaucratic organizations. They play an important role not only in the public sector, but also in large private enterprises. It is difficult to imagine how some decisions can be made in a different way in a modern society. Bureaucracy is based on a methodological consideration of a decision's pros and cons and has been regarded as particularly rational (Weber 1922). Bureaucratic decisions have significant disadvantages, including a lack of efficiency, unnecessary expenses, slowness, inflexibility, and an inherent tendency to growth (Niskanen 1971; Niskanen 2012).

Negotiations play an important role in sectors of the economy and society characterized by positions of power. Examples include conflicts between unions and management, between oligopolistic suppliers, and especially between organized interest groups and the government or state administration (e.g. Ostrom 1998). Producer interests are often more easily aligned and dominate the scattered interests of consumers and taxpayers. 
In addition to the four social decision-making systems discussed above (see Dahl and Lindblom (1953), more could be adduced. For instance, decisions according to tradition have been dominant in many societies (Frey and Pommerehne 1990).

This paper argues that decisions by random mechanism is an additional social-decisionmaking system which can fruitfully be applied to corporate governance, politics, science and culture, as developed in the next section.

\section{Applications of random selection procedures}

\section{Representation of stakeholders in corporations}

One of the main problems of modern enterprises is the high-handed behavior of managers. Although they are employees, they have a distinct informational advantage over the representatives of shareholders (supervisory board or board of directors), and even more so over the shareholders as a whole. This dilemma is the object of principal-agency theory (Jensen and Meckling 1976). It focuses on aligning the interests of managers to that of the company by linking their remuneration to company profits. This overlooks the fact that the managers have ample possibilities to set the terms of their contracts and even to influence the size of profits declared. They have a strong incentive to engage in such manipulation - which is reflected in the skyrocketing executive salaries.

In contrast, the interests of stakeholders are neglected unless they can protect themselves by contracts. Zeitoun et al. (2014) propose a different construction. A second chamber for stakeholder representation should be established in addition to the existing representation of shareholders as a first chamber. The members of the second chamber are randomly chosen from the various stakeholder groups. These groups are defined by the fact that they cannot protect their firm-specific investments. In addition to employees, these groups include suppliers, customers and politicians as representatives of the public sector. Such a construction allows a representation of concerns that might otherwise be neglected. At the same time, the influence of vested and undesirable interests is curtailed. A random selection allows the introduction of ideas which would otherwise tend to be overlooked or marginalized by the existing decision-makers within the enterprise. Since the first chamber consists of shareholders' representatives, it would be desirable to incorporate other aspects than those 
considered by experts. The lack of knowledge and information of randomly selected stakeholder representatives may thus be compensated by new and unusual ideas.

The two chambers can be assigned different tasks. The two chambers of a company may be given completely equal rights (such as the National Council and the Council of States in Switzerland), or the second chamber may be given a merely advisory capacity. In between, we can conceive of many possibilities. Thus, the stakeholders' representatives only get a say in certain transactions, for example in the selection of the executives and their salaries.

\section{Political Sector}

In the political sector, one of the two chambers of parliament can be selected using a random mechanism. In ancient Athens, the members of the Boule, the main decision-making body, were randomly selected from the citizens of the City of Athens (women and non-citizens were excluded). The candidates had to pass a test, the Dokimasia, in which they had to answer questions and had to defend themselves against accusations, for example, whether they were loyal to the emerging democracy or whether they were sympathetic to an oligarchic system (Headlam 1891; Mulgan 1984; Buchstein 2009b).

This procedure might also be applicable to the appointment of the U.S. House of Representatives. As is well documented, economic interest groups and the established party leadership has large, if not overriding, power (Wright 1990; Cox and McCubbins 2005). Only a candidate receiving their support has a realistic chance of being elected. This influence disappears in a random sample taken from the population of all citizens. A significant advantage would be that the cost in terms of time and money spent decline strongly. For the last congressional elections in October 2012, an estimated total of \$ 3.7 billion was spent, i.e. on average not less than $\$ 8.5$ million for one seat ${ }^{3}$. These expenditures are not socially productive and can even be harmful. Other notable proposals to change the US Constitution are, for instance by McCormick (2006, p. 159-160) suggesting a "Tribunal Assembly" of 51 randomly chosen individuals; Zakaras (2010) proposing replacing state and federal Senates by citizens' chambers, filled by lot; or by Callenbach and Phillips (1985), Burnheim (2006) and O’Leary (2006). Dahl (1987) and Fishkin (1991) consider a body of individuals deliberating on policy issues.

\footnotetext{
${ }^{3}$ http://www.opensecrets.org/bigpicture/, accessed on January 14, 2014
} 
Random selection is also applicable to the executive branch, where certain formal minimum qualifications could be introduced as selection conditions. For example, the seven members of the Swiss Federal Council could be randomly selected from the members of the two chambers of the Federal Parliament. Over a longer period of time, this automatically secures representation according to the strength of the party, gender, religion and region (Frey and Steiner 2012).

In some countries, especially in the United States and the United Kingdom, random selection is used in the judiciary to determine the members of a jury. In the U.S., the impartiality of the lot is limited by the fact that the conflicting parties may refuse individuals as jury members for alleged or actual bias. The appointment of jurors through a lottery has a long tradition. The membership in the Heliaia, the people's court of classical Athenian democracy, was determined by lot. In 1791, following the first phase of the French Revolution, the composition of the courts in criminal trials was determined by chance. Lay judges are often considered to be better trial judges, to possess important everyday experience, and to pay more attention to standards of fairness than professional judges. However, lottery as a recruitment procedure for jurors is globally the least used method. Most jurors are selected by administrative officers (Buchstein 2009b).

Random selection could fruitfully be applied to international organizations (Frey and Stutzer 2005). International organizations tend to suffer from fundamental democratic deficits. Binding political participation rights for citizens reduces this deficit. They may launch initiatives, vote in referendums and dismiss members of the Executive. Due to their large number, it appears difficult to involve all citizens of member countries in such referendums. A random selection of trustees exercising their democratic rights can solve this problem. This form of direct participation has the potential to overcome democratic deficits and the lack of efficiency that characterizes international organizations.

\section{Science}

A large literature deals with the significant problems of selecting articles from those submitted to scientific journals (Laband and Tollison 2003; Gillies 2008; Frey and Osterloh 2014; Spiegel 2012). In many disciplines (science, medicine, and more recently, economics), publications in 
professional journals are essential to an academic's career. Junior academics who publish an insufficient number of articles or in less prestigious journals will not receive a professorship. Two to five referees today determine the selection of articles, a process which has now been identified as creating significant distortions. The correlation between their reports is generally low (Starbuck 2005), and particularly novel and unusual contributions have little chance to prevail against the resistance of mainstream referees. However, a random selection among the articles submitted could overcome this problem. Obviously incompetent submissions can be directly rejected and particularly excellent contributions can be accepted directly (as is routinely done today via desk rejections and the acceptance of papers based e.g. on presidential speeches). A random selection among the remaining articles submitted offers the chance for unconventional and particularly innovative papers to be published. At the same time, outsiders with few or no personal connections, who do not come from famous universities, and even situated outside academia have a reasonable likelihood of being published. The random procedure would help to open up more or less closed academic circles and thus support innovative new ideas and approaches. Whether such a system achieves these goals could be checked empirically. A scholarly journal can, for instance, deal with half of the submissions in the conventional way via referee reports, and subject the other half to random selection. After some time has passed, it can be analyzed whether the randomly selected articles are cited more or less frequently than comparable papers selected by reviewers.

\section{Culture}

The sites on the UNESCO List of Global Heritage of Mankind, which now number almost one thousand, have become major attractions for cultural tourism and are icons of national identity (see e.g Harrison and Hitchcock 2005; Leask and Fyall 2006). The World Heritage List is generally considered to be an excellent effort to save the globe's common history in the form of cultural monuments and landscapes worthy of preservation. It is, however, bureaucrats, experts and politicians who select the sites. As a consequence, representativeness is severely distorted. A clear case in point is that over half of the sites are located in Europe, while hardly any natural or cultural sites are located in Africa (Frey and Steiner 2011). This violates the formal Global Strategy for a Balanced, Representative and Credible World Heritage List, decided by the World Heritage Committee in 1994, which calls for a more equal distribution of Heritage Sites among continents and countries. Empirical studies reveal that there is a 
direct correlation between participating in UNESCO's main decision-making body and representation on the List (Frey et al. 2013). Countries which are members of the World Heritage Committee can put sites on the List with a significantly higher probability of being accepted.

A random selection of sites would reduce such unwarranted political influences and ensure a broad representation (Steiner and Frey 2011). The sites to be put on the World Heritage List can be chosen by lot from among all sites considered acceptable by experts. In addition, all acceptable sites can be weighted by the classifications of the experts. This procedure would ensure representation of all acceptable sites. As a consequence, governments would find it less attractive to invest money and effort in promoting a property, because the final selection is beyond their influence. A possible disadvantage may be that a random selection would not provide the same prestige as what is claimed to be a serious choice by the World Heritage Committee. To circumvent this problem, though, random selection could take place one step ahead. The 21 members of the World Heritage Committee could be selected by lot from the 186 member countries of the UNESCO Heritage Convention. Random selection of the Committee members would make ex-ante bargaining, strategic voting, and logrolling less effective.

\section{Concluding Remarks}

This paper discusses and proposes an unusual procedure as decision-making mechanism. Many people consider a random procedure - in the sense of using a mathematical probability - to be a rather strange decision-making mechanism and may therefore oppose it. Rationality and "common sense" seem to be violated, as the decision is left to an anonymous and external mechanism.

Empirical studies show that in the perception of the general population the method of random decision performs poorly compared to decisions by public authorities, by simple voting processes and by the use of the price system (Frey and Pommerehne 1990). However, random procedures have played a significant role in history, especially in classical Greece and the medieval city-states in Italy. Chance as an aid in decision-making processes has often been considered in a positive light by major thinkers. Aristotle even went so far as to consider 
political decisions only to be democratic if they were made by lot (Buchstein 2009b). He considered votes and elections not to conform to the democratic ideal because important families exert too much influence.

We have examined the important positive features of decisions by random mechanisms. Above all, random processes allow representativeness with respect to individuals or groups that would be difficult to achieve otherwise. A random selection would account for each group according to their weight in the population (at least in the long run or when decisions are made repeatedly). For example, on average, the proportion of women and of racial minorities selected by random mechanisms will correspond to their share in the population. Representativeness also applies to ideas and ideologies, especially if they are difficult to detect by an exogenously imposed quota. Random selection guarantees a diversity of views essential for a dynamic society. An anonymous random mechanism would reduce existing discrepancies in society. No relevant group could be excluded from decision making for any extended period. All groups would have the opportunity to accomplish some of their goals in the future. Random mechanisms significantly reduce interested parties' capacity to influence political decisions by means of bribery and corruption. Finally, they also decrease the large expenses that are associated with today's democratic election campaigns.

While there are also clear disadvantages of random mechanisms, we argue that they can largely be overcome. In comparison to the many advantages of random mechanisms, they are often of lesser importance.

The paper argues that random mechanisms can be applied fruitfully to a wide range of fields. These include politics, the judiciary, the economy, science and the cultural sector. We aim at demonstrating that random procedures are not restricted to the few applications used today but that there are a great many possibilities to profit from this social decision-making system. This limits necessarily an in-depth discussion of each of these applications. It must be left to future research.

It is important to embed the random selection process in appropriate institutions. In a few cases, it is reasonable to make decisions solely on the basis of random processes. The model of the Venetian Republic, which prospered for centuries, shows that it is possible to combine election procedures and random decisions very successfully. Of course there are certainly areas in which random selection must be ruled out as the only decision-making process, but 
our goal in writing this paper will have been achieved if random selection procedures are considered more seriously than is presently the case.

\section{References}

BFS. 2011. "01 Bevölkerung." In Die neue Volkszählung. Neuchåtel: Bundesamt für Statistik BFS; Eidgenössisches Department des Innern EDI.

Boochs, Wolfgang, ed. 2009. Geschichte und Geist der Koptischen Kirche. 2 ed. Aachen: Bernardus-Verlag.

Boulding, Kenneth Ewart. 1968. Beyond economics: essays on society, religion, and ethics: University of Michigan Press Ann Arbor, MI.

Buchstein, Hubertus. 2009a. "Bausteine für eine aleatorische Demokratietheorie." Leviathan 37 (3):327-52.

—. 2009b. Demokratie und Lotterie: Das Los als politisches Entscheidungsinstrument von der Antike bis zur EU. Vol. 70: Campus Verlag.

_. 2010. "Reviving Randomness for Political Rationality: Elements of a Theory of Aleatory Democracy." Constellations 17 (3):435-54.

Burnheim, John. 2006. Is Democracy Possible?: The Alternative to Electoral Democracy: Sydney University Press.

Callenbach, Ernest, and Michael Phillips. 1985. A citizen legislature: Banyan Tree Books.

Carson, Lyn, and Brian Martin. 1999. Random selection in politics: Praeger Publishers.

Condorcet, Marquis de. 1795. Esquisse d'un tableau historique des progrès de l'esprit humain. Paris: Diannyaere.

Cox, Gary W, and Mathew D McCubbins. 2005. Setting the agenda: Responsible party government in the US House of Representatives: Cambridge University Press.

Dahl, Robert A. 1987. "Sketches for a democratic utopia." Scandinavian Political Studies 10 (3):195-206.

Dahl, Robert Alan, and Charles Edward Lindblom. 1953. Politics, economics, and welfare. New York: Harper.

Dumler, Helmut. 2001. Venedig und die Dogen. Düsseldorf: Artemis \& Winkler. 
Duxbury, Neil. 1999. Random justice: on lotteries and legal decision-making: Clarendon Press.

Elster, Jon. 1989. Solomonic judgements: studies in the limitation of rationality: Cambridge University Press.

Fishkin, James S. 1991. Democracy and deliberation: New directions for democratic reform. Vol. 217: Cambridge Univ Press.

Frey, Bruno, and Margit Osterloh. 2014. "Rankings games." Evaluation Review (forthcoming).

Frey, Bruno S, Paolo Pamini, and Lasse Steiner. 2013. "Explaining the World Heritage List: an empirical study." International Review of Economics:1-19.

Frey, Bruno S. 1983. Democratic Economic Policy: A Theoretical Introduction. Oxford: Robertson.

Frey, Bruno S., and Werner W. Pommerehne. 1990. "On the Fairness of Pricing - An Empirical Survey among the Gerneral Population." Journal of Economic Behaviour and Organization 20:295-307.

Frey, Bruno S., and Lasse Steiner. 2011. "World Heritage List: Does it Make Sense?" International Journal of Cultural Policy (17):5.

_. 2012. "Zufallswahl des Bundesrates." Weltwoche.

Frey, Bruno S., and Alois Stutzer. 2005. "Ein Vorschlag zu mehr Demokratie in Internationalen Organisationen." Zeitschrift für Staats- und Europawissenschaften 3 (3):344-61.

Gillies, Donald. 2008. How should research be organised?: College Publications.

Hansen, Mogens Herman. 1991. The Athenian democracy in the age of Demosthenes: structure, principles and ideology: University of Oklahoma Press.

Harrison, David, and Michael Hitchcock. 2005. The Politics of Heritage. Negotiating Tourism and Conservation. Channel View. Clevedon, UK: Channel View Publications.

Hayek, Friedrich A von. 1979. The Political Order of a Free People. Vol. 3 of Law, Legislation, and Liberty. London

Headlam, James Wycliffe. 1891. Election by lot at Athens: The University Press.

Hirschman, Albert O. 1970. Exit, voice, and loyalty: Responses to decline in firms, organizations, and states. Vol. 25: Cambridge, Mass.: Harvard University Press. 
Intriligator, Michael D. 1973. "A Probabilistic Model of Social Choice." Review of Economic Studies 41: 553-60.

Jensen, Michael C., and William H. Meckling. 1976. "Theory of the Firm: Managerial Behavior, Agency Costs and Ownership Structure." Journal of Financial Economics 3 (4):305-60.

Kant, Immanuel, ed. 1795. Zum Ewigen Frieden, Kants gesammelte Schriften. Edited by K. P. A. d. Wissenschaft. Photomechanical reproduction ed. Vol. 8. Berlin und Leipzig.

Laband, David N, and Robert D Tollison. 2003. "Dry holes in economic research." Kyklos 56 (2):161-73.

Leask, Anna, and Alan Fyall. 2006. Managing World Heritage Sites. Amsterdam: Elsevier Manin, Bernard. 1997. The principles of representative government: Cambridge University Press.

McCormick, John P. 2006. "Contain the wealthy and patrol the magistrates: restoring elite accountability to popular government." American Political Science Review 100 (2): 147 .

Merrill, Samuel, and Jack Nagel. 1987. "The effect of approval balloting on strategic voting under alternative decision rules." The American Political Science Review:509-24.

Montesquieu, Charles L. 1749. De l'esprit des lois. Paris: Garnier.

Mulgan, Richard G. 1984. "Lot as a democratic device of selection." Review of Politics 46 (4):539-60.

Niemi, Richard G. 1984. "The problem of strategic behavior under approval voting." The American Political Science Review:952-8.

Niskanen, William A. 2012. "Gordon Tullock: A contribution to bureaucracy." Public Choice $152(1-2): 97-101$.

Niskanen, William A., Jr. 1971. Bureaucracy and Representative Government. Chicago, IL: Aldine Press.

O'Leary, Kevin. 2006. Saving democracy: A plan for real representation in America: Stanford University Press.

Olken, Benjamin A. 2010. "Direct democracy and local public goods: Evidence from a field experiment in indonesia." American Political Science Review 104 (2):243-67.

Olson, Mancur. 1965. The logic of collective action: public goods and the theory of groups. Cambridge, MA: Harvard University Press. 
Ostrom, Elinor. 1998. "A behavioral approach to the rational choice theory of collective action: Presidential address, American Political Science Association, 1997." American Political Science Review:1-22.

Silvano, Giovanni. 1990. "Florentine republicanism in the early sixteenth century." Machiavelli and Republicanism:40-70.

Smith, Adam. 1776. An Inquiry into the Nature and Causes of the Wealth of Nations.

Spiegel, Matthew. 2012. "Reviewing less: Progressing more." Review of Financial Studies 25 (5):1331-8.

Starbuck, William H. 2005. "How much better are the most-prestigious journals? The statistics of academic publication." Organization Science 16 (2):180-200.

Steiner, Lasse, and Bruno S Frey. Selecting World Heritage sites: A new proposal. CEPR 2011 [cited 7.3.2013. Available from http://www.voxeu.org/article/what-wonderfulworld-picking-unesco-world-heritage-sites.

Stone, Peter. 2009. "The Logic of Random Selection." Political Theory 37 (3):375-97.

Weber, Max. 1922. Wirtschaft und Gesellschaft. Tübingen: Marianna Weber.

Wright, John R. 1990. "Contributions, lobbying, and committee voting in the US House of Representatives." The American Political Science Review:417-38.

Zakaras, Alex. 2010. "Lot and Democratic Representation: A Modest Proposal." Constellations 17 (3):455-71.

Zeitoun, Hossam, Margit Osterloh, and Bruno Frey. 2014. "Learning from Ancient Athens: demarchy and corporate governance." The Academy of Management Perspectives 28:1-14. 